\title{
An Indication of China's Policy towards Uighurs and its Implications by International Law Aspects
}

\author{
Mellisa Towadi 1 \\ Nur Mohamad Kasim² \\ Rumawi $^{3}$ \\ Siti Asifa Tahir ${ }^{4}$
}

1Faculty of Law, Gorontalo State University. Email: mellisatowadi@ung.ac.id
2Faculty of Law, Gorontalo State University. Email: $\underline{\text { nurkasim@ung.ac.id }}$
3Faculty of Sharia, IAIN Jember. Email: rumaw@iain-jember.ac.id
4Faculty of Law, Gorontalo State University. Email: yooanggun27@gmail.com

\section{Article Info}

Kata Kunci :

Indication; China's

Policy; Uighur;

Implications;

International Law.

\section{How to cite (APA}

Citation Style):

Towadi, M., Kasim.

N.M., Rumawi.,

Tahir, S.A. (2021). “

An Indication of

China's Policy

towards Uighurs

and its Implications

by International

Law Aspects".

Jambura Law

Review. JALREV 3

(1): 55-71

(C) 2021-Towadi, $M$.

Under the license CC BY-SA 4.0

\begin{abstract}
This article examines the Chinese government's policy towards Uighurs for the purpose of outlining and explaining indications of the policy that have implications on the legal aspects of this international law. This study was researched using normative juridical methods with expansive analysis based on logical-normative approaches. The results of the analysis show that broadly the policies China implements against the Uighur population are indicated to acts of discrimination. China's main interest is sovereignty, so of course, China will not allow the release of any territory from China. While the implications in the context of International Law as to uphold the guarantee of civil and political rights, liberal and democratic principles or independence, and individual freedom in relation to the state. The points of conflict identified, especially concerning the reach of equality of rights between ethnic Uighurs and other ethnicities in China, the prohibition of inhumane punishment and degrading dignity, and religious freedom.
\end{abstract}




\section{Introduction and Overview}

Uighurs are an ethnic Turkish sub-division living mainly in a place referred to by the Chinese government as XUAR (Xinjiang Uighur Autonomous Region) and called East Turkistan by Uighur activists in the People's Republic of China. China's most recent 2010 annual census informs that the Uighur population now lives in Xinjiang or Eastern Turkistan around 10 million. $^{1}$

However, according to some sources, Erkin Alptekin argues, the actual number of Uighurs is much higher than the official population estimated at more than 18 million. As reported by Ablet Kamalov, there are also large Uighur diasporic communities in the Central Asian countries of Kazakhstan, Kyrgyzstan, and Uzbekistan, which are estimated to reach half a million people. This is in addition to the nearly 150,000 Uighurs believed to live in Pakistan, Afghanistan, Saudi Arabia, Turkey, Western Europe, and North America. ${ }^{2}$

The Uighurs are from Xuar in north-western China, on the border with Central Asia. Covering one-sixth of the country's total territory, XUAR is a large but sparsely populated area with about 19 million inhabitants. About 8 million of the population is Turkish-speaking Uighur Muslims, concentrated in the southern part of the region around cities such as Kashgar, known to the Chinese as Kashi, located 2,500 miles west of Beijing. Uighurs (pronounced Wee-gurs) make up about $45 \%$ of Xuar's population. ${ }^{3}$

"Uighur", meaning unity or fellowship. Their ancestors were probably part of the Ding Ling wandering tribe of northwest China who lived near Lake Baikal. They lived between the Irtish River and Lake Balkhash, around the third century AD. Around the

1 Lidya Elmira Amalia. (2018). Skripsi: "Diskriminasi Rasial Terhadap Minoritas Muslim Uighur di China Ditinjau dari Hukum Islam”. Yogyakarta: Fakultas Ilmu Agama Islam Univeristas Islam Indonesia. Hal 42

2 Ibid.

3 M. Rayila. (2011). "The Pain of nation: The Invisibility of Uyghurs in China proper". The Equal Rights Review, Vol. 6, 2011: 45 
middle of the ninth century AD, the area was occupied by Turkey. Scattered Uighurs gradually gathered in the Yutian area. ${ }^{4}$

Xinjiang is again named by the Ching Dynasty (Manchu). Long before Ching was a country in the 18th century, the country was named after East Turkistan. The word "Turkistan" means "territory of the Turks" and prays for the northern Sir River region of Central Asia. ${ }^{5}$

Xinjiang as a region and Uighur as a nation has strategic significance for China. This is due to several factors inherent in Xinjiang and Uyghur, both endogenous and exogenous factors. The endogenous factor intended here is the inherent Uyghur, especially the identity variable. While the exogenous factor is a variable derived from the 'outer' of the Uyghur, such as natural resources and geographical position. Both endogenous and exogenous factors are two things of equal significance, which causes Xinjiang and Uyghur to encourage China's domestic and foreign. As these factors determine the future of China, the Xinjiang region and the Uyghurs get high priority from Beijing. 6

Xinjiang's location among the great civilizations of Islam and rich in oil and coal has made the region very strategic. Xinjiang's inhabitants by the Uyghurs who are part/descended from Turkey. The Uyghurs are the largest ethnic group in Xinjiang, reaching $45 \%$ of the total 19 million inhabitants. The Uyghurs began converting to Sunni Islam in the 10th century. Citing Conway's assertions, though often described as a minority of Chinese Muslims, Uyghur Islam is not a monolith, and not all narratives or identities about Uyghur nationalism are related to Islam. ${ }^{7}$ They are also famously gifted in art and have beautiful folk works, including the epic poem "Fu Le Zhi Hui"

\footnotetext{
${ }^{4}$ Anshari Thayyib. (1991). "Islam di China". Surabaya: Amapress. p. 26

${ }^{5}$ Dhurorudin Mashad. (2006). "Muslim di China". Jakarta:Pensil. p.5

${ }^{6}$ Baiq L.S.W. Wardhani. (2011). " Masyarakat, Kebudayaan dan Politik: Respons Cina atas Gerakan PanUyghuris di Provinsi Xinjiang”. http://journal.unair.ac.id Vol 24, IV (Oktober-Desember 2011): 292301

7 Ibid,. Hal. 95
} 
(wisdom and happiness) and the divertimento music and dance "Er Shi Mu Ka Mu" (twelve faces).

These people are also known to be very skilled in agriculture, such as gardening and growing cotton. They are also adept at weaving carpets, Uighur hats, and making knives. But in China, the group is reportedly not living freely. China implemented a law restricting the personal rights of ethnic Uighur Muslims to the point of detention that it discussed with "camps." This is known from a detention report obtained by the United Nations in August 2018. The report said there were about one million Uighurs and other Muslim groups detained in Xinjiang. In the camp, they reportedly underwent a re-education program or Political Indoctrination Camp in which there was an attempt to descend the beliefs embraced by Uighurs. They are also restricted in terms of movement, barred from exiting China and into other territories within China. ${ }^{8}$

\section{Problem Statement}

Some of China's policies towards Uighurs are heard for the purpose of preventing radicalization and extremism in the region, and others are aimed at the development of the Uighur region, but the implementation of those policies is beginning to become absurd. That policy indicates human rights violations and attacks on tribes.

\section{Method}

This study was researched using juridical methods normative with an expansive analysis based on a logical-normative approach. The data results are traced to normative juridical use of the Constitution of the People's Republic of China in 1982, the International Convention on Human Rights Violations in general and the Principles of Islamic Law. This Normative material is then used as a reference in explaining the current conditions that occur in Uighurs using a logically normative approach, that

\footnotetext{
${ }^{8} \mathrm{CNBC}$ Indonesia. (ed. December 22, 2019). "Mengenal Muslim Uighur". https://www.cnbcindonesia.com/tech/20191222082454-37-124974/mengenal-muslim-uighurmengapa-kini-jadi-viral/3, Retrieved January 21, 2020
} 
china's laws and regulations on Uighurs are placed as reasonable conclusions and indicated on the intended results.

\section{Discussion}

\subsection{Indication and Implementation of China's Policy on Ethnic Uighurs}

China is a country located in the East Asia region and is also five of the permanent members of the United Nations Security Council. China is also a rapidly growing multiethnic country with 56 ethnicities, one of which is ethnic Uigyur Muslims in Xinjiang Province. ${ }^{9}$

Uighur Muslims in Xinjiang Province received poor treatment from the Chinese Government, according to a Cable News Network (CNN) report in 2016 the Chinese government implemented a new education policy that prohibits parents and teachers from including their children in various religious activities. The new rules take effect from nov. The Chinese government said parents and mentors caught doing so would be reported to the police. Although the Chinese Communist Government formally declares religious freedom, minority groups such as the Uighur Muslim Settlers in Xinjiang are not allowed to participate in religious activities. In recent years the government has even cracked down on Unregistered Islamic schools or madrassas in Xinjiang. China also prohibits religious attributes such as beards or headscarves. ${ }^{10}$

\footnotetext{
${ }^{9}$ Wina, A. T. (n.d.). Eprints UMM. Retrieved Juni 22, 2020, from Skripsi "Diplomasi Publik Pemerintah Tiongkok melalui China Radio International (CRI) Indonesia tentang Kehidupan Umat Muslim di Tiongkok: http://eprints.umm.ac.id/36193/2/iiptummpp-gdl-ayutriwina-50060-2-babi.pdf

10 Suastha, R. D. (2016, October 12). China Kembali Berangus Kebebasan Beragama Muslim Uighur. Retrieved June 2, 2020, from Indonesia: https://m.cnnindonesia.com/internasional/20161012020346-113-165025/china-kembaliberangus-kebebasan-beragama-muslim-uighur
} 
A British Broadcasting Corporation (BBC) report in 2018 found a large, tight-security complex emerged, complete with a two-kilometer outer wall and 16 guard substations. ${ }^{11} \mathrm{~A}$ UN committee has reported that up to one million Uighurs and other Muslim groups are detained in the western Xinjiang region, where they undergo socalled 're-education' programs. ${ }^{12}$

According to Human Rights Watch, Uighurs in particular, are closely monitored. They have to provide biometric and DNA samples. There have been reported arrests of those with relatives of 26 countries deemed 'sensitive'. And up to a million people have been detained. Human rights groups say people in the camps were forced to learn Mandarin and directed to denounce, even abandon their priestly beliefs. ${ }^{13}$

Several former detainees told the BBC about the physical and psychological abuse they experienced in detention camps. Their entire family vanished, and they said the prisoners were tortured physically and mentally. The BBC has seen evidence of almost total surveillance of Muslims in Xinjiang. ${ }^{14}$

Whereas the freedom of variety has been clearly set out in Article 18 DUHAM which states: "Everyone has the right to freedom of thought, belief, and religion; this right includes the freedom to change religion or belief in teaching, worship, worship and obedience activities, whether alone or equally with others, in public or in private". Even

\footnotetext{
${ }^{11}$ Sudworth, J. (2018, October 26). Investigasi BBC: Cina Dirikan Kamp-kamp Rahasia untuk 'Mendidik' Umat Muslim Uighur di Xinjiang. Retrieved June 2, 2020, from BBC Indonesia: https://www.google.com/amp/s/www.bbc.com/indonesia/amp/dunia-45962686

12 Hughes, R. (2018, December 19). Muslim Uighur dan Perlakuan China terhadap Mereka yang Perlu Anda Ketahui. Retrieved June 4, 2020, from BBC Indonesia: https://www.google.com/amp/s/www.bbc.com/indonesia/amp/dunia-46601638

13 Ibid.

${ }^{14}$ Ibid.,
} 
at the International Convention Civil on Political Rights (ICCPR) in more detail, religious freedom is set out in Articles 18,19,20, and 27.15

The above provisions are very different from the practice if we look at what is happening in China today. But it turns out that the Chinese state is the only one among the permanent members of the UN Security Council who do not join or have not ratified the ICCPR which guarantees important rights, including the right to religious freedom, the right to a court, an independent and impartial tribunal, freedom of expression, and political participation through free elections. Instead of aiming to shape the lives of ethnic Uighurs better, China's policies can instead be intended to be a gross human rights violation. Various programs were established and forcibly implemented for ethnic Uighurs, including:

\section{a) Mass Internmant and Re-Education Programs}

The regional government of Xinjiang (Xinjiang Uygur Autonomous Region (XUAR)) is running two massive Education programs with its support from Beijing. The first is the forced international program, in which an estimated one million Uighurs have been detained indefinitely due to the international process they have to go through on the basis of the Xinjiang region policy. Even former prisoners of the program (credible sources) in a review of the report by the Committee on the Elimination of Racial Discrimination ${ }^{16}$ describing the content of abuse in this international program in the form of abuse, including the reduction of forced sleep, beatings, and people being hung from ceilings and walls to the compulsion to abandon their religious beliefs or consume alcohol and meat (haram) in order to violate their religious practices (program prisoners). So the Committee on the Elimination of Racial Discrimination (CERD) condemned this training program which was declared an educational program with a 'no rights zone' i.e. an area without Rights.

\footnotetext{
15 Ibid., Hal. 62

16 UNHR. (2018, August 13). United Nations Human Rights Office of the High Commissioner. Retrieved Juni 10, 2020, from Committee on the Elimination of Racial Discrimination Reviews the Report of China: https://www.ohchr.org/EN/NewsEvents/Pages/DisplayNews.aspx?NewsID=23452\&LangID=E
} 
The second program implemented an educational program, in which Uighurs were forced to study Mandarin, sing songs about China, and attend weekly flag-raising ceremonies. China Human Rights Defenders estimates that the collectively detained population of Xinjiang for both programs is approximately 3 million out of a total of 10 million Uighur population in Xinjiang.

The locus of the program is common in the Southern Xinjiang region where the majority of the Uighur population lives. The Financial Times reported in August that an estimated $80 \%$ of adults in urban environments had been forcibly removed, most of whom were young and middle-aged, and then confirmed to participate in international and reeducation programs. Only the elderly and those who are classified as manageable are not recruited in the training and reeducation program. Meanwhile, Chinese government authorities are placing children (whose parents are prisoners in training programs) into orphanages. Then on October 1, Free Asia radio reported that China had forcibly relocated the reeducation programs in secret and sent them to detention centers as far away as Heilongjiang province in China's East Sea. ${ }^{17}$

\section{b) Anti-Islamic Programming}

In addition to international and reeducation programs, XUAR government has also imposed a number of restrictions on religious and cultural practices in Uighurs. As Josh Rogin reported for the Washington Post, the U.S. government has demolished thousands of religious buildings, banned Uighurs from wearing long beards, banned the use of Islamic-meaning names for newborns, and built crematoriums to quell Islamic burial traditions in Uighurs. ${ }^{18}$

17 Hurd, H. (2018, Oktober 9). China's Human Rights Abuses Against Uighurs in Xinjiang. Retrieved Juni 18, 2020, from Lawfare: https://www.lawfareblog.com/chinas-human-rights-abuses-againstuighurs-xinjiang

18 Rogin, J. (2018, Agustus 3). Ethnic cleansing makes a comeback - in China. Retrieved Juni 18, 2020, from Washington Post: https://www.washingtonpost.com/opinions/global-opinions/ethnic- 
Meanwhile, the government has also enacted a new surveillance system to monitor the movements of certain populations and groups in the Uighur region. As the Wall Street Journal reported, the amount of surveillance equipment used for every 100 thousand people in Xinjiang is equal to what is used to monitor more than one million people in other parts of China. ${ }^{19}$ All Uighurs are required to install such surveillance apps on their phones, which automatically transfer audio files and other personal data to external servers. In addition, some families have been forced to be able to allow communist party officials to stay in their homes. Elsewhere, authorities in this surveillance system place barcode codes in the family's residence. QR scans are carried out when the government visits a resident's home for the purpose of verifying the population information in each house. The implementation of the policy was affirmed by Human Rights Watch, which allowed the policy of supervising the occupants of the house to visitors in every house in Uighurs and then questioned the purpose of the arrival of the guests. $^{20}$

Broadly speaking, the policies China implements against the Uighur population are indicated to acts of discrimination. Although China has the sovereignty to govern its people by issuing various policies, it cannot renege on universal human rights values and the 1948 DUHAM that countries believe and adopt internationally. Moreover, China is one of the countries that belongs to the UN Security Council, which indications

cleansing-makes-a-comeback--in-china/2018/08/02/55f73fa2-9691-11e8-810c5fa705927d54 story.html

${ }^{19}$ Chin, J. (2017, Desember 19). Twelve Days in Xinjiang: How China's Surveillance State Overwhelms Daily Life. Retrieved Juni 22, 2020, from The Wall Street Journal: https://www.wsj.com/articles/twelvedays-in-xinjiang-how-chinas-surveillance-state-overwhelms-daily-life-151370035

20 HumanRightsWatch. (2018, September 9). "Eradicating Ideological Viruses" China's Campaign of Repression Against Xinjiang's Muslims. Retrieved Juni 22, 2020, from Human Rights Watch: https://www.hrw.org/report/2018/09/09/eradicating-ideological-viruses/chinas-campaignrepression-against-xinjiangs 
of discrimination from china-issued policies according to the 1998 Rome Statute of Limitations can extend to gross human rights violations.

Although China did not ratify the Rome Statute of 1998, respecting the rules in it is already a moral obligation for UN member states to submit to the statute. In addition to the Constitution of the People's Republic of China 1984 (hereby abbreviated as The 1982 China's Contitution) in chapter II the Fundamental Rights and Duties of Citizens has governed the fundamental rights of its citizens both generally adopting the international principle of equality before the law (article 33 of the 1982 China's Contitution) and specifically related to the above policy which is the basic right of chinese citizens in article 33 to article 56 of the 1982 China's Contitution.

While from the perspective of Islamic Law that the highest purpose of sharia (maqashid al shariah) is to realize the welfare of all people. This is in line with the 1990 Cairo Declaration on Human Rights in Islam by the Organization of Islamic Cooperation (OIC) emphasizing similar aspirations in its muqaddimah by expressing the desire of Muslim countries to be involved in efforts to uphold human rights in any country around the world, to protect people from exploitation and persecution, affirming freedom and the right to a dignified life in accordance with the guidance of Islamic sharia.

\subsection{Legal Implications}

The Chinese government is a very authoritarian government and seeks to subjugate the opposition in various ways. This was suggested by Susanne Schroter, director of the Global Islamic Training Centre at Johann Wolfgang von Goethe University in Frankfurt. Schroter added that the Chinese government's methods apply only to Uighurs and could be to all money groups demanding liberalization or democratization in the Chinese state. There used to be a Falun-Gong movement that was overridden in extreme ways. The Chinese government often uses separatist and terrorism grounds to justify its policies towards the Uighurs. The means used such as persecution, maximum intimidation, and forced labor camps called reeducate camps are ways that according to International Law constitute acts of human rights violations. 
Although China promised through the 1982 Chinese constitution to guarantee human rights for its citizens. Even China is the party that ratified the four international conventions governing Human Rights, among others:

- International Convention on the Elimination of All Forms of Racial Discrimination (ICERD) ratified by China in 1981;

- Convention on the Elimination of All Forms of Discrimination Against Women (CEDAW) ratified since 1980;

- The United Nations Convention against Torture and other Cruel, Inhuman or Degrading Treatment or Punishment (UNCAT) ratified in 1988;

- International Convenant on Economic, Social and Cultural Rights (ICESCR) ratified by China in 2001 .

Forced detention in the form of reeducate camps, discrimination, intimidation to religious oppression of Uighurs arguably violates each of the above conventions. ${ }^{21}$ For example, article 1 of ICERD defines "discrimination as the distinction, exclusion, restriction or preference based on race, color, descent, or national or ethnic origin" which means discrimination is a distinction, exclusion, restriction or preference based on color, race, national or ethnic origin with the purpose or consequence of negating, undermining beliefs which constitute fundamental freedoms in political, economic, social, cultural and other areas of public life.

Convention on the elimination of all forms of discrimination against women (CEDAW, ratified by China in 1980); and the Convention Against Torture and the cruel, inhuman, or degrading treatment of dignity or punishment (UNCAT), which was ratified in 1988. Forced detention and religious oppression of Uighurs arguably violates each of these Conventions. For example, Article I of the International Convention on the elimination of all forms of racial discrimination defines discrimination as "differences, exclusions, restrictions or preferences based on race, color, ancestry, or national or ethnic origin"

\footnotetext{
${ }^{21}$ Wantu, F.M., \& Sarson, M.T.Z (2020). Legal Protection of Women as Victim of Domestic Violance. Indonesia Journal of Advocacy and Legal Service, 1 (2), 243-258
} 
with the purpose or consequence of negating or undermining beliefs is a fundamental freedom in political, economic, social, cultural or other areas of public life.

In addition to reeducation, forced internment, beard ban, ban on Muslim activities, the prohibition of Islamic naming for newborns imposed by the Chinese government on the basis of their religion, ethnicity, and identity of the Uighur population, clearly in Article 1 ICESCR explicitly recognize " peoples have the right of self-determination" and thus "by virtue of that right" can "freely determine their political status and freely pursue their economic, social and cultural development" that all nations have the right to self-determination that includes freely determining political status, free to earn a decent livelihood in the context of freely pursuing their economic, social, and cultural development. Even in reservations regarding the scope of the "people" of the ICESCR convention, China does not show a broader interpretation, in other words, China fully approves the content of the ICESCR convention.

Meanwhile, the UNCAT convention on Article 12 expressly calls on every country "to ensure that its competent authorities proceed to a prompt and impartial investigation, wherever there is reasonable ground to believe that an act of torture has been committed in any territory under its jurisdiction". This Convention ensures that any competent party is authorized to conduct a swift, impartial investigation of indications of mistreated such as acts of torture or severe discrimination occurring in its jurisdiction. In addition, the Chinese government is also indicated to be violating the CEDAW convention on the policy of placing Uighur children in orphanages while their parents are detained in camps.

Not only ratifying the four conventions above, but China also signed the International Covenant on Civil and Political Rights (ICCPR) or the international convention on Civil Rights and Political Rights in 1998 although it has not ratified the convention. However, the 2009-2010 National Human Rights Action Plan of China (NHRAP) specifically lists the ICCPR as one of the fundamental principles of the action plan and includes a commitment in the action plan to advance the rights recognized by the ICCPR convener, including a ban on torture, detention that violates human rights law. 
By an Islamic perspective, the Qur'an expressly promotes diversity in human nature and culture and prohibits the use of this diversity as a basis for discrimination among people. On the contrary, human diversity is shown as a foundation for knowing each other and appreciating the power and wisdom of God as the creator of man. Related to ethnic diversity QS Al Hujurat verse 13 states:

"Oh, humans! Indeed, We created you from a male and a female and made you into peoples and tribes so that you may 'get to' know one another. Surely the noblest of you in the sight of Allah is the most righteous among you. Allah is truly All-Knowing, All-Aware."

In addition, the 1982 Chinese Constitution recognizes the extensive rights associated with harm in Xinjiang. Article 4 expressly prohibits any action that undermines national unity, article 22 protects "valuable historical sites and cultural monuments, Article 35 recognizes freedom of speech, from the press, assembly, association, procession, and demonstration. While Article 36 says that " [n]o state organs, public organizations or individuals may compel citizens to believe in, or not believe in, any religion" in which no state organization, public organization, or individual can compel its citizens to believe, or do not believe in, any religion. Interestingly Article 36 goes on to say that the state will protect "normal" religious activities but does not say what the "normal" religious activities mean.

Thus ethnic or racial discrimination prohibited under Islamic Law is implicitly not justified in the 1982 Chinese constitution and as a result, the rights of ethnic minorities to enjoy their culture must be protected without discrimination. The problem of religious minorities in Uighurs requires more elaboration than ethnic minorities. In general, on the issue of religious differences QS Al Kafirun verses 1-6 (with emphasis) include:

"Say: O you who disbelievers! I do not worship what you worship. And you are not worshippers of the Lord whom I worship. And I have never made a worshiper of what you worship. And you have never been worshippers of the Lord whom I worship. For you is your religion, and for me is my religion."

The entire analysis reveals that sharia does not oppose or prohibit guarantees of civil and political rights, liberal and democratic principles, or independence and individual 
freedom in relation to the state. The points of conflict identified, especially concerning the reach of equality of rights between ethnic Uighurs and other ethnicities in China, the prohibition of inhumane punishment and degrading dignity, religious freedom. Islamic law a domestic law in approximately 50 Muslim countries from less than 200 countries in the world including those of the United Nations. It is certainly Islamic law that can universally serve as a vehicle for the full trapping of civil and political rights guaranteed by the result that Muslim countries not only consider themselves bound by international legal obligations but also bound by religious obligations to respect and guarantee the civil and political rights set out in the ICCPR international convention.

In addition to respecting Uighur religious beliefs and laws, more important than that is that China should pay attention to its international cooperation relations with islamic countries, especially China with most OIC countries are establishing cooperation in the Belt and Road Initiative. Even in addressing the Uighur conflict, the OIC continues to implement non-intervention, respect China's sovereignty and recognize religious and ethnic diversity, so it is also important for China to uphold the same principles of international law. ${ }^{22}$

\section{Conclusion}

China implemented a policy to curb the actions of extremists and separatists targeted by Uighur movement groups for the Chinese government. Of all the policies generally systemized on two programs are Mass Internment and Re-Education Programs and Anti-Islamic Programming. Broadly speaking, the policies China implements against the Uighur population are indicated to acts of discrimination. Although China has the sovereignty to govern its people by issuing various policies, it cannot renege on universal human rights values and the 1948 UDHR that countries believe and adopt

\footnotetext{
${ }^{22}$ Nur M.K., Mellisa. T., \& Dolot A.B. (2020).” The Organization of Islamic Cooperation Affects to China through the Islamic Law Approach Addressing the Uighur Conflict: Is it Possible?". Journal of Legal, Ethical and Regulatory Issues (JLERI), Volume 23 Special Issue 2: 1-14. https://www.abacademies.org/journals/month-july-year-2020-vol-23-issue-0-journal-jleri-pastissue.html
} 
internationally. Moreover, China is one of the countries that belong to the UN Security Council, which indications of discrimination from china-issued policies according to the 1998 Rome Statute of Limitations can extend to gross human rights violations.

Policy analysis shows that China's main interest is sovereignty, so of course, China will not allow the release of any territory from China. Those causes certainly cannot be released from how valuable Xinjiang is to the Chinese government. Xinjiang means it is strategically and economically important to China. However, to maintain policy and sovereignty is impossible if the government loses the trust of the people (Uighurs in particular) towards its country because the absolute condition of state sovereignty is the existence of a society that complies with its constitution and government.

While the implications in the context of International Law reveal that in line with the principles of islamic law so as to uphold the guarantee of civil and political rights, liberal and democratic principles or independence, and individual freedom in relation to the state. The points of conflict identified, especially concerning the reach of equality of rights between ethnic Uighurs and other ethnicities in China, the prohibition of inhumane punishment and degrading dignity, religious freedom in line with the arrangements in the International Convention of Civil and Political Rights.

\section{References}

Amalia, Lidya Elmira. (2018). Skripsi: “ Diskriminasi Rasial Terhadap Minoritas Muslim Uighur di China Ditinjau dari Hukum Islam". Yogyakarta: Faculty of Islamic Sciences, Islamic University of Indonesia. p. 42

Chin, J. (2017, Desember 19). Twelve Days in Xinjiang: How China's Surveillance State Overwhelms Daily Life. Retrieved Juni 22, 2020, from The Wall Street Journal: https://www.wsj.com/articles/twelve-days-in-xinjiang-how-chinassurveillance-state-overwhelms-daily-life-151370035

CNBC Indonesia. (edisi 22 Desember 2019)."Mengenal Muslim Uighur". Dilansir dari https://www.cnbcindonesia.com/tech/20191222082454-37-

124974/mengenal-muslim-uighur-mengapa-kini-jadi-viral/3 , Retrieved January 21,2020

Hughes, R. (2018, December 19). Muslim Uighur dan Perlakuan China terhadap Mereka yang Perlu Anda Ketahui. Retrieved Juni 4, 2020, from BBC Indonesia: https://www.google.com/amp/s/www.bbc.com/indonesia/amp/dunia46601638 
Hurd, H. (2018, October 9). China's Human Rights Abuses Against Uighurs in Xinjiang. Retrieved June 18, 2020, from Lawfare: https://www.lawfareblog.com/chinashuman-rights-abuses-against-uighurs-xinjiang

HumanRightsWatch. (2018, September 9). "Eradicating Ideological Viruses" China's Campaign of Repression Against Xinjiang's Muslims. Retrieved Juni 22, 2020, from Human Rights Watch: https://www.hrw.org/report/2018/09/09/eradicating-ideologicalviruses/chinas-campaign-repression-against-xinjiangs

Kasim, Nur Mohamad., Towadi, Mellisa., \& Bakung, Dolot A. (2020).” The Organization of Islamic Cooperation Affects to China through the Islamic Law Approach Addressing the Uighur Conflict: Is it Possible?". Journal of Legal, Ethical and Regulatory Issues (JLERI), Volume 23 Special Issue 2: 1-14. https://www.abacademies.org/journals/month-july-year-2020-vol-23-issue-0journal-jleri-past-issue.html

M. Rayila. (2011). “ The Pain of nation: The Invisibility of Uyghurs in China proper”. The Equal Rights Review, Vol. 6, 2011: 45

Mashad, Dhurorudin. (2006). "Muslim di China”. Jakarta:Pensil. Hal .5

Rogin, J. (2018, Agustus 3). Ethnic cleansing makes a comeback - in China. Retrieved Juni 18, 2020, from Washington Post: https://www.washingtonpost.com/opinions/global-opinions/ethnic-cleansingmakes-a-comeback--in-china/2018/08/02/55f73fa2-9691-11e8-810c5fa705927d54_story.html

Suastha, R. D. (2016, October 12). China Kembali Berangus Kebebasan Beragama Muslim Uighur. Retrieved Juni 2, 2020, from CNN Indonesia: https://m.cnnindonesia.com/internasional/20161012020346-113165025/china-kembali-berangus-kebebasan-beragama-muslim-uighur

Sudworth, J. (2018, Oktober 26). Investigasi BBC: Cina Dirikan Kamp-kamp Rahasia untuk 'Mendidik' Umat Muslim Uighur di Xinjiang. Retrieved Juni 2, 2020, from BBC

Indonesia: https://www.google.com/amp/s/www.bbc.com/indonesia/amp/dunia45962686

Thayyib. Anshari. (1991). "Islam di China”. Surabaya: Amapress. p. 26

UNHR. (2018, August 13). United Nations Human Rights Office of the High Commissioner. Retrieved Juni 10, 2020, from Committee on the Elimination of Racial Discrimination Reviews the Report of China: https://www.ohchr.org/EN/NewsEvents/Pages/DisplayNews.aspx?NewsID=23 452\&LangID $=\mathrm{E}$

Wantu, F.M., \& Sarson, M.T.Z (2020). Legal Protection of Women as Victim of Domestic Violance. Indonesia Journal of Advocacy and Legal Service, 1 (2), 243-258 
Wardhani, Baiq L.S.W.. (2011). “ Masyarakat, Kebudayaan dan Politik : Respons Cina atas Gerakan Pan-Uyghuris di Provinsi Xinjiang”. http://journal.unair.ac.id Vol 24, IV (October-December 2011): 292-301

Wina, A. T. (n.d.). Eprints UMM. Retrieved Juni 22, 2020, from Skripsi "Diplomasi Publik Pemerintah Tiongkok melalui China Radio International (CRI) Indonesia tentang Kehidupan Umat Muslim di Tiongkok: http://eprints.umm.ac.id/36193/2/jiptummpp-gdl-ayutriwina-50060-2babi.pdf 